\title{
Exploring the Roles of Parents and Students in EFL Literacy Learning: A Colombian Case
}

\author{
Sergio Aldemar Hurtado Torres ${ }^{1} \&$ Harold Andrés Castañeda-Peña ${ }^{2}$ \\ ${ }^{1}$ Master's Programme of English Didactics, Universidad Surcolombiana, Neiva, Colombia \\ ${ }^{2}$ Interinstitutional Doctoral Programme in Education, Universidad Distrital Francisco José de Caldas, Bogotá, \\ Colombia \\ Correspondence: Sergio Aldemar Hurtado Torres, Master's Programme of English Didactics, Universidad \\ Surcolombiana, Neiva, Colombia. Avenida Pastrana, Carrera 1, Office 239. Tel: (57)-(8)-875-9164 Ext. \\ 1084-1187. E-mail: maestriadidacticaingles@usco.edu.co
}

Received: August 16, 2016 Accepted: September 18, 2016 Online Published: September 19, 2016

doi: 10.5539/elt.v9n10p156 URL: http://dx.doi.org/10.5539/elt.v9n10p156

\begin{abstract}
There is little scholarly information about parent involvement in their children's English as a Foreign Language (EFL henceforth) literacy learning in the Colombian context. This exploratory-qualitative study looks into the possible roles of parents and children in EFL literacy learning at home, with special emphasis on parental roles and contributions. The study has a three-fold purpose: (1) to describe the behaviour of parents and students when doing EFL literacy tasks at home, (2) to explore feelings and thoughts (perceptions) of parents and students about working together on EFL literacy tasks at home, and (3) to identify ways in which parents contribute to a student's EFL learning. Sixteen ninth grade students at a state school, and their parents or caregivers, carried out a series of EFL literacy tasks in their respective homes. Video recordings, field notes, qualitative interviews, and surveys were used as data collection tools. The results demonstrate that even when parents do not have a command of the English language, they have the potential to help with EFL learning from a non-linguistic point of view (e.g. monitoring children's homework, providing learning conditions, shaping children's minds for EFL by giving advice, and feedback about EFL homework development).
\end{abstract}

Keywords: parental involvement, EFL literacy learning, home EFL literacy tasks, parents' roles, students' roles

\section{Introduction}

This investigation took place in El Doncello-Caquetá, Colombia. Sixteen ninth grade students at a state school, and their parents or caretakers, carried out a series of EFL literacy tasks in their respective homes. These tasks aimed to create suitable situations in which parents can demonstrate a repertoire of helping actions in favour of their children's EFL learning, without training on what to do. Video recordings, field notes, qualitative interviews, and surveys were implemented as data collection tools. This research aimed to characterise the behaviours, attitudes, feelings and perceptions of students and parents, while developing EFL literacy tasks at home. Although the main concern of this study is parental involvement, the students' actions, reactions, and perceptions are important for reaching a better understanding of parent roles and behaviour in the EFL learning process.

According to Henderson and Mapp (2002), cooperation between parents and schools may be more helpful in obtaining better results in children's learning than parents and schools working separately. From the perspective of the varied benefits attributed to parental involvement (e.g. Brannon \& Dauksas, 2012; Petchprasert, 2014; Widding \& Berge, 2014) and homework (e.g. Avila Daza \& Garavito, 2009; Walker, Hoover-Dempsey, Whetsel, $\&$ Green, 2004), it appears useful to investigate these issues in Caquetá-Colombia. It is popularly thought that parents are the first and most valuable teachers for children (Brannon \& Dauksas, 2012; MEN, 2016). This makes sense considering the time that parents normally share with their children at home. Parents can become a valuable source and support for children in education (Kukk et al., 2014; Widding \& Berge, 2014). This can be applied in the context of children learning a foreign language, because English learning is part of education. Parents may be in the best position to influence a student's learning, considering influential factors resulting from research such as parents' beliefs and attitudes (Cojocariu \& Mares, 2014), parent-teacher cooperation (Widding \& Berge, 2014), and the parent's style of education (Necsoi et al., 2014). In some families, other relatives, such as siblings, take the role of parents (Gregory, 1998), and they may have much to offer a student's 
EFL learning. In view of this evidence, parents could be potential helpers in their children's EFL learning.

Previous studies have suggested that events outside the English language classroom may affect children's learning. For example Senechal, LeFevre, Thomas, and Daley (1998) noted that parents are able to support children's literacy learning through reading storybooks at home. Avila Daza and Garabito (2009) found that a parent's help with their children's homework has positive effects on a student's EFL learning. These kinds of events outside the EFL classroom, and more specifically in children's homes, may be a great opportunity for exploring the contributions that parental involvement may offer to student EFL literacy learning.

This qualitative study investigates whether children are missing the valuable help that parents could provide in a student's EFL learning process. To approach this problem, the present study explores the possible roles of parents and children in a student's EFL literacy learning, with special emphasis on parental roles and contributions.

This study considers the researchable problem of whether students are missing the potential help that parents may offer in their children's EFL literacy learning. In Colombia, where English is taught as a foreign language, teaching English becomes a challenging task. It is necessary to explore what is happening beyond the English foreign language classroom in the search for alternative pedagogical sources or emergent EFL pedagogies to improve the EFL teaching-learning processes. This exploration of parents' actions and general behaviours while working with their children on EFL literacy tasks at home may be a good starting point.

\subsection{Literature Review}

Ávila Daza and Garavito (2009) studied the implementation of English language homework as a strategy to create connections between parents and schools. This study worked on the importance of involving parents in their student's school life. These authors found that parents' participation in their children's EFL homework tasks benefitted children's learning of a foreign language. Brannon and Dauksas (2012) worked on the idea that reading out loud to children is one of the best means of parental involvement. These researchers recommended assigning literacy activities as homework. They perceive parental storybook reading to have a positive influence on the development of early literacy skills of children.

Petchprasert (2014) found that children's development of lexicon is favoured by parental dialogic reading. Lee and Bowen (2006) argued that less educated parents may show lower levels of involvement in their children's school activities as a result of factors such as lack of knowledge of the school system, or past negative experiences in education. Xuesong (2006) viewed parental involvement more as a strategy to increase a student's learning outcomes than as simple cooperation. For these authors, the participation of parents was positively related to children's language learning.

\subsubsection{The Concept of Parental Involvement in EFL Literacy Learning}

Parental involvement in EFL literacy learning is seen as a multidimensional construct (Ringenberg et al., 2009) and thus, parental involvement in children's EFL literacy learning is a compendium of parent's actions that can be directly or indirectly related to their children's EFL literacy learning. Necsoi et al. (2012) confirmed that parents' actions reported in research include the supervision and application of rules at home, parent-children communication, monitoring of a student's activities at home. Bakker and Denessen (2007) have also identified actions such as checking homework, communicating with teachers, participating in a student's school activities, supervising children's behaviour outside the school, limiting television watching time, applying disciplinary rules for children and controlling time with friends.

\subsubsection{Background of Parental Involvement in Student Learning and Its Relationship to EFL Literacy Learning}

Parental involvement has been attributed to many important education outcomes and EFL learning. Brannon and Dauksas (2012) emphasised that parental involvement offers many benefits including better results in elementary and secondary school. He et al. (2015) confirmed that parents take part in children's learning and school performance by offering cognitive and emotional support to students at home. These researchers demonstrated that parental help with homework positively affects the interest of students in the completion of school assignments and organisation of study time at home. Necsoi et al. (2012) pointed out that the manner in which parents exercise their authority may contribute to a student's outcomes. Baumrind (1971) proposed a classification of parental styles that includes three main types of parents: permissive parents (those who do not expect children's mature behaviour), authoritarian parents (those who demand a lot from children and provide little feedback), and authoritative parents (those who demand a lot from their children and provide support). According to Necsoi and her colleagues, children perform better in school if they have authoritative parents. Authoritative parents are described as those who demonstrate high levels of warmth, supervision, and promotion 
of psychological autonomy.

Henderson and Mapp (2002) argue that parental involvement influence variables such as standardised tests, students' involvement in challenging academic activities, promotion from one course to the next, class attendance, home and school behaviour, adaptability, and social interaction at school. Pavalache-Ilie and Tirdia (2014) report that a parent's most important educational actions are maintaining communication with children, offering help with homework, talking about learning progress and school issues, taking children to extra classes, being in contact with the school (Henderson \& Mapp, 2002), and monitoring children's social and psychological environment regarding school success (Hoover-Dempsey et al., 2005).

Most of the previously mentioned parental contributions to education may apply also to EFL learning since it is part of education. In language learning research, parental involvement is usually seen as a factor that contributes to learners' language development (Xuesong, 2006). Chen and Harris (2009) state that parents' knowledge about their children, and parents' beliefs in regard to literacy practices influence a student's literacy learning. From the work of Er et al. (2012), parents are thought to be able to help in the language development of their children; for example parents' can contribute to a student's literacy development by reading stories to their children.

Cojocariu and Mares (2014) describe negative influential factors as "barriers in parental involvement" (sic) (p. 654). For these authors, this term refers to the varied diminishing, restricting and conditioning factors that may prevent parents from getting involved in their children's learning. The more salient barriers to parental involvement categorised by Cojocariu and Mares (2014) are parent's feelings of inferiority; economic issues, single parent families, a parent's doubts about being competent to help with homework, absence of parent-school communication, a parent's ignorance of their children's school lives, low educational level of parents, and the perception that only the school is responsible for education.

Many previous studies on parental factors and parental involvement in EFL learning demonstrated that having parents involved is a student's EFL learning is beneficial (e.g. Widding \& Berge, 2014; Necşoi, Porumbu \& Beldianu, 2013; Brannon \& Dauksas, 2012; Cojocariu \& Mares, 2014; and Ávila Daza \& Garavito, 2009). Other researchers suggest that it is not only parents who have an important role to play in language learning. Literacy learning in particular is co-constructed between the learner and other members of the family or the community. Those members can be siblings (Gregory, 1998, 2001); grandparents (Jessel, Kenner, Gregory, Ruby, \& Arju, 2011); or people with whom the learners interact in their daily activities (Volk \& De Acosta, 2001). The Likert scale used with this study's participants showed that there is a low level of parental participation in their children's EFL learning at Jorge Abel Molina (JAM) School. This suggests the hypothesis that children are possibly missing the valuable help that parents could provide in EFL learning.

\subsubsection{The Role of EFL Homework}

For Kukk et al. (2014) homework functions include practicing, using and confirming a lesson's content, cultivating independent habits of study that favour discipline, and increasing a student's interest in the subject. For these authors, homework increases learning efficiency, demonstrates learning outcomes, prepares students for tests, and favours the development of intellectual skills. "Homework supports learning in at least one of four ways: pre-study, comprehension, practice and processing. Homework can be used as an introduction to a topic or provide a more comprehensive understanding of the material" (Kukk et al., 2014).

Kukk et al. (2014) suggested that parents assume part of the responsibility for homework development when their help is added to children's efforts in completing homework tasks. Parents also act as are providers of resources, locations, encouragement and support for studying during homework time. In this sense, parent-teachers cooperation is necessary to increase the usefulness of homework. "Teachers and parents should work together in creating a supportive homework environment" (Kukk et al., 2014). A positive attitude from parents in regard to homework affects positively children's attitudes and increases the potential of higher academic outcomes (Kukk et al., 2014).

\section{Method}

The present study aims to explore the varied roles, feelings, and perceptions of students and parents while developing EFL literacy tasks at home; and the manners in which parents may contribute to children's EFL literacy learning. To accomplish these objectives, this study uses a qualitative research approach, through exploratory and descriptive research (Hernández, Fernández, \& Baptista, 2006). According to Hatch (2002) qualitative studies explore natural settings, as in the case of parents and students undertaking EFL literacy tasks at home. Heigham and Croker (2009) confirmed that qualitative studies include settings such as homes, workplaces, and classrooms. Hatch (2002) indicated that these types of investigations focus on the participant 
perspectives, and the researcher is seen as an instrument for data gathering. In such instances, the collection of data is carried out by means of instruments such as participant observations (field notes), artefacts, transcriptions from interviews, literacy events, and open-answer surveys (Hatch, 2002).

\subsection{The Research Question}

The present research project aims to answer the question "What contributions do parental involvement in children's EFL literacy tasks make to the EFL outcomes of ninth grade students at Jorge Abel Molina School?" In general, the research design is qualitative. Data is collected on parents' behaviour, as they engage in EFL literacy tasks with their children. It is expected that once parents are immersed in the homework process they will probably exhibit a variety of helpful actions and behaviours that favour children's EFL learning.

\subsection{Participants}

The participants of this qualitative study are 16 ninth-grade students and their parents or caregivers. The learners were aged between 13 and 16 years old. They studied at Jorge Abel Molina School. The relationships between the adults and the students were varied; one aunt, two older sisters, one father, one mother-in-law, and ten mothers. Purposive sampling was implemented when selecting the population for this study. Dawson (2002) explains that purposive sampling is a good option when the purpose of the study is to describe rather than to make generalisations. As explained in Dawson (2002), a purposive sample allows the researcher to make a selection of participants according to the specific objectives of the study and many aspects that the researcher finds relevant for consideration. In the development of the study, I was a teacher participant. I am the designer of the research actions as well as the instruments and basic materials such as the home EFL literacy tasks, the surveys, and the qualitative interviews. I am also a participant observer. Guest et al. (2012) explained that being a participant observer is not simply being part of a social environment; being a participant observer includes accomplishing the role of a researcher and all that it implies (recording voices, sounds, and images; taking notes, and try to develop interpretations of behaviours by means of questions designed for that goal). As part of the ethical responsibility for a research process, the participants signed a consent letter which they gave their agreement and approval to participate in this research study. In this case, as the students were younger than 18 years of age; the parents were the ones with the power to grant approval. Jorge Abel Molina School was also informed of the development of the present qualitative study by means of a notification letter.

\subsection{General Research Procedure}

The pedagogical actions in this study began with four EFL lessons (one per week), in which one EFL literacy task per lesson was assigned to the 16 students. Field notes and video-tapes were taken from the lessons as part of the observation process. The complete of the EFL literacy tasks took place in students' homes. The interactions between students and parents were observed. Field notes and video-tapes were taken from the home interactions of three students and their parents. The EFL literacy tasks produced final outcomes that were taken as artefacts. By the end of the four weeks of pedagogical actions, semi-structured interviews were held with the three students and their parents. Field notes were also taken as part of the observation process. For the rest of the sample (thirteen students and their parents), open answer surveys were used. Interviews and surveys aimed to gather information about the feelings and thoughts of parents and students with regard to their experiences in completing EFL literacy tasks together at home. Every piece of data gathered was transcribed and then analysed using the software "Atlas.ti". The areas of the analysis were roles, feelings and thoughts of the parents and students.

\subsection{Data Collection Instruments}

Qualitative interviews, surveys, observations, and artefacts were the data collection instruments in this study. Richards in Heigham and Croker (2009), explained that a qualitative interview is a conversation which has a purpose, and its objective is to explore a respondent's experience and views. In this study, the interviews took place at the homes of parents and students, in their natural daily-environment, and as spontaneous conversations between students and parents and the researcher. As reported by Warren in Gubrium and Holstein (2002), the context is part of the data and is something that cannot be taken away from the process of interviewing. In the present qualitative study, surveys are open response questionnaires. According to Brown in Heigham and Croker (2009), an open response questionnaire is a list of questions intended to explore the participant's thinking about a pre-determined topic; and the items include a blank space for all the respondents to answer in their own words. These questionnaires were effective as an alternative means by which to gather information from parents and students considering the challenges of interviewing the entire sample. The specific research situation where the researcher was a language teacher means that the type of observation was 'participant observation'. According to Cowie in Heigham and Croker (2009), being a participant observer involves two actions at the same time; 
participating in the phenomena explored and observing a pre-determined context. Field notes were taken as part of the observation process, and as a complement to other data collection procedures. Hopkins (2002) reported that field notes are a strategy to report observations, reflections and reactions. The results of the EFL literacy tasks developed by students with the help of parents at home are seen as 'artefacts' in this study. As reported by Heigham and Sakui in Heigham and Croker (2009), artefacts can take different forms, such as results of exams, past English grades, lesson handouts, or past videos or pictures.

\section{Findings}

Because of the qualitative character of the study and the data gathered, this investigation used the software "ATLAS.ti" for qualitative data analysis. This software facilitates the systematisation of the data collected from observations, interviews, surveys, and artefacts. All the data collected were transcribed into rich text format documents. in this way, the data were loaded onto the Atlas.ti platform, where the analysis was carried out as per the grounded approach to data analysis. The processing of data through Atlas.ti included five steps; codifying, establishing categories, establishing relationships among categories, producing an analytical model from Atlas.ti, and analysing data in the search for possible answers to the research question in light of the theory available. The analytical model produced from Atlas.ti was analysed in search of the varied roles that parents may assume while helping their children in the development of home EFL literacy tasks; roles that somehow may imply a contribution to a student's EFL literacy learning.

The hermeneutic unit for this analytical model is "Home EFL Literacies". That unit includes two large categories, which themselves include a series of codes that represent the roles undertaken by parents and students, and the thoughts and perceptions of parents and students. The first big category is "Parent's Roles". It contains four sub-categories; "Valuing Parent's Roles in Children's EFL Learning", "Offering Feedback", Facilitating EFL Learning", and "Shaping a Child's Mind Toward EFL". The second big category is "Student Roles". This category contains four sub-categories; "Valuing Parental Involvement in EFL Learning", "Managing Information", "Responding to Parents", and "Approaching EFL Learning". Both big categories share a code, which is labelled "Having Fun While Doing Homework".

Analysis of the category "Parent's Roles" assumed that the roles assumed by parents are actions that may contribute to a student's EFL learning. Analysis of the sub-category "Shaping a Child's Mind Toward EFL" suggests that parents are able to transform children's minds with regard to EFL by giving advice for EFL success. This can be seen in the excerpts below. Social interactions between parents and children at home may serve as sources of social capital that may favour students' EFL. According to Kim (2011), social capital may be seen as a way for students to take advantage of being members of social circles that offer them positive advice, encouragement, and models to follow. In this case, parental advice for EFL success may favour children's EFL learning.

\section{P 2: First EFL Literacy Task Student 1.rtf - 2:31 (34:34)}

M: Tiene que ponerle arto cuidado a esto del inglés porque usted... mejor dicho... tiene que repasar más y hacer más esfuerzo para que le vaya bien en ingles.

[Pay a lot of attention to this English thing because you... I mean ... you have to study more and make an effort so that you do well in English]

\section{P84: Interview parent 1.rtf - 84:18 (55:55)}

Uno se da cuenta que el inglés es muy importante... entonces como que más le digo a él $<<$ bueno amor, póngase pilas en esto para que mejore, porque el inglés prácticamente hoy en día es muy indispensable>>.

[One realises English is very important... so I insist on telling him "love, smarten up in this thing so you will get better because English is indispensable nowadays"]

Analysis of the subcategory "Facilitating EFL Learning" showed that parents facilitate EFL learning by being providers of information and providers of materials and resources. During the development of the EFL literacy tasks assigned as homework, children asked parents about the information required for the homework and parents answered and offered the necessary information. In those moments, parents were information providers. Lee and Bowen (2006) explain that social capital can take the form of information. In this sense, the information obtained from parents may be used by children as tools for accomplishing EFL homework. The excerpts below show that parents and students agree on the existing capacity and willingness of parents to provide time, learning materials, and other resources that facilitate a student's learning. According to Volk and De Acosta (2001), parents are a big source of help; and such help can take the form of material and non-material things, both human, and other resources. These ethnographers suggest that those resources benefit a student's literacy development. 
From this perspective, parents may contribute to children's EFL literacy learning by facilitating learning conditions that include time, learning materials, and other resources, such as searching for sources.

\section{P102: Survey 2.3 FOR STUDENTS.rtf - 102:7 (70:70)}

El tiempo para la tarea y tener los materiales y la ayuda de mis padres fue lo que ellos me ayudaron.

[Having time for homework and getting my materials and my parents help... that was what helped me]

P88: Interview Student 2 J.rtf - 88:16 (49:49)

Y sobre todo cuando necesito diccionario... o que se me acabó el lápiz, que necesito fotocopias... siempre ella me ayuda.

[Mainly when I need the dictionary... or when I have no pencil or when I need to make copies... she always helped me]

\section{P86: Interview parent 3.rtf - 86:6 (23:23)}

En algunas tareas yo digo "yo no entiendo eso, vaya a internet y averigüe". Cuando no entiendo... "vea allá hay un libro de inglés, vaya busque allá en la caja".

[At times I say "I don't get it go and check on the internet". When I don't understand... "look at that book in English over there, go and find it in the book shelf"]

\section{P97: Survey 1.7 FOR PARENTS.rtf - 97:6 (72:72)}

$\mathrm{Si}$, uno les puede ayudar así no sepa uno inglés, pero uno se le facilita formas de que investiguen.

[Yes, one can help them even if one doesn't know any English... one just gives them sources to research]

The data analysis of the sub-category "offering feedback" showed that parents provide feedback during children's EFL learning process by monitoring children's performance. According to Necsoi et al. (2012), checking homework is a means of parental involvement. Excerpts below show how parents monitor children's performance in EFL homework.

\section{P 2: 2-Transcription of First EFL Literacy Task Student 1.rtf - 2:1 (4:4)}

M: ¿Qué es lo que le dejaron de tarea?

[M: What's your homework about?]

\section{P85: Interview parent 2.rtf - 85:7 (37:37)}

Está uno pendiente. “¿Qué le dejaron hoy? ¿Qué tiene hoy? ¿Hay que colaborarle hoy? ¿En que hay que colaborarle?" entonces esta uno como más pendiente de ellos.

[One is just aware of the homework. "What did they assign you today? What's up for homework? Do you need any help with homework? How can I help you?... so one is more aware of their homework]

\section{P104: Survey 2.5 FOR STUDENTS.rtf - 104:6 (54:54)}

Mi mamá siempre está revisando todo lo que tenemos que hacer en el colegio.

[My mum always checks what we have for school work]

Another way in which parents offer feedback include giving assistance with homework (Ringenberg et al., 2009), and becoming leaders of the task. This last idea is demonstrated in the excerpt below; the parent reported that she feels that homework is a matter for both parent and child, and not only the student. Parents may assume such an empowered role as a response to their inner feelings of being co-responsible for the EFL assignment (Kukk et al., 2014).

\section{P85: Interview parent 2.rtf - 85:11 (55:55)}

P: precisamente al involucrarme yo en las tareas, al ver si si, si no, porque uno siente que no es una tarea solo de él sino una tarea de dos. Porque como salga él va a salir uno. Si sale mal él, entonces yo no le enseñé... yo no le ayudé... yo no le colaboré como debía.

[... specifically this happens when I get involved in the school homework, just to see you know, because one feels it is not just his homework it's our homework. If he does well also I have done well. If he doesn't do well then I feel I didn't teach him... I didn't help him...I didn't support him as I should have]

The analysis of the category "Student Roles" was according to the idea that the roles assumed by students are a result of the parent's participation in the completion of EFL literacy tasks at home. The sub-category "Managing 
Information" showed that students gather and process the information related to the homework by actions such as taking notes, checking information or content, and asking for parent's knowledge. From the sub-category "Responding to Parent", it was possible to establish that students respond to a parent's monitoring and feedback by explaining EFL strategies, reporting homework advances and results, and explaining literacy tasks. From the sub-category "Approaching EFL Learning", it was found that parent's actions during the completion of EFL homework provoked children's actions such as using parent's knowledge and co-constructed knowledge in literacy tasks, using parent's feedback in the EFL assignments, making decisions, asking for parent's feedback, and asking for parent's help with homework.

Those actions undertaken by students during the completion of EFL homework are seen as actions provoked by the influence of parental involvement. A student's behaviours may be different if parents do not participate in EFL assignments. According to He et al. (2015) the critical roles assumed by parents support children at cognitive and emotional levels. He and his colleagues (2015) found that parental support positively influences children's organisation of study time and their interest in accomplishing homework. Desforges and Abouchaar (2003) confirm that parents are influential agents in a student's tasks instructions. Petchprasert (2014) argued that parental positive attitudes and beliefs about language learning contribute to children's L2 development. Similarly, Kukk et al. (2014) suggest that children's attitudes are affected by parental attitudes in regard to homework, and consequently, students may obtain higher school outcomes.

\section{Discussion}

The data analysis and findings section shows that parents can shape children's minds for EFL by giving children advice about EFL success. This is the social capital that parents pass on to their children by giving positive advice, encouragement, and models to follow. In that sense, homework is more useful when parents encourage students in school assignments. Having parents involved in school activities benefits children's attitudes and study skills.

Parents can facilitate a student's EFL learning in at least two ways: 1) Providing information to children and 2) providing learning conditions (materials, time, and resources). As argued before, the social capital that parents pass on to children can take the form of information (Lee \& Bowen, 2006). In that sense, cultural capital from parents also takes the form of experiential knowledge. In other words, children acquire cultural knowledge from social interactions with parents. Information can also be used by students as tools to accomplish EFL homework. For these reasons, parents are the providers of material and non-material resources.

Parents can offer feedback to students during the development of home EFL literacy tasks. Parents offer feedback in various ways: 1) Monitoring children's performance; 2) Giving feedback on EFL homework; 3) Processing information: as parents are co-responsible for the EFL assignment (Kukk et al., 2014); 4) Giving clarification: when parents give feedback (He et al., 2015); 5) Becoming leader of the task.

It needs to be acknowledged in the ELT field that checking homework is part of parental involvement simply because parental actions include assisting with the accomplishment of homework (e.g. making corrections). Lee and Bowen (2006) note that cultural capital can take the form of home rules, and learning values (e.g. rules and values about learning materials use). This is why parental involvement includes helping students to do homework (e.g. organizing the task) even when parents do not master the target language. According to Kukk et al. (2014), once parents are involved in children's homework, they assume co-responsibility for the homework completion. However, parents must be sure of their understanding of the elements of the task to be able to help properly. They give clarification in an attempt to make sure the feedback given is effective; because they feel co-responsible for the EFL homework as was also discussed by Kukk et al. (2014). Drawing on previous ideas, parents become leaders of an EFL assignment because they feel the responsibility of the tasks is theirs too, and not only the child's.

Parental involvement in a student's EFL literacy tasks provoked specific child behaviour in regard to EFL literacy learning, such as managing information (taking notes, checking information or content, and asking for parent's knowledge), responding to parents (explaining EFL strategies, reporting back to parents, and explaining a literacy task), approaching EFL learning (making decisions, asking for feedback, asking for a parent's help with EFL homework, and using a parent's knowledge, co-constructed knowledge, and feedback in EFL literacy tasks). These student actions are seen as a response to parent's emotional and cognitive support, parent's task orientations, parent's positive attitudes and beliefs about EFL, and parent's attitudes in regard to EFL assignments. These considerations lead to the following conclusions. 


\section{Conclusions}

Taking into account the previous discussion, it was possible to offer the following conclusions.

Parents contribute to the EFL literacy learning of the ninth grade students of Jorge Abel Molina School by shaping children's minds toward EFL in aspects such as attitudes to studying EFL, attitudes toward EFL homework, and views of EFL. Parents also contribute to a student's EFL literacy learning by facilitating EFL learning. This is done by providing cultural capital for children in the form of information and experiential knowledge within parents-students social interactions. Therefore, parents' provision of learning conditions in EFL literacy learning include material and non-material resources for study and organising study time at home.

Another parental contribution to children's EFL literacy learning is offering feedback to students about the development of their EFL homework. Parents offer feedback by monitoring children's performance in EFL homework. They are also co-responsible for the EFL assignment with actions such as giving feedback in EFL homework, processing information, providing clarification, and becoming leaders of the task development. These last findings appear to be new to the specialised literature. It suffices to say however that these new findings are context-sensitive.

Being actively involved in a student's EFL homework is a good parental contribution to children's EFL learning. When parents help in the accomplishment of a student's EFL assignments children assume a variety of positive roles in EFL learning and EFL homework as result of the influence of parental attitudes, parents' cognitive and emotional support, and parents' tasks orientations. Consequently, children may gain confidence about accomplishing tasks and obtain better EFL learning outcomes. We recommend that English language teachers see parents as helpers in the EFL process and to value the potential of parental contributions to students learning from home. EFL teachers should create pedagogical spaces in which parents take part; in this way, parents may gain confidence and become more useful in the EFL process. It is recommended that schools redefine the role of parents in relation to EFL homework, and give parents more recognition in the school curriculum.

\section{References}

Avila Daza, N. P., \& Garavito, S. J. (2009). Parental involvement in English homework tasks: Bridging the gap between school and home. Issues in Teachers' Professional Development, 11(2), 105-115.

Bakker, J., \& Denessen, E. (2007). The concept of parent involvement. Some theoretical and empirical considerations. International Journal about Parents in Education, 1(0), 188-199.

Baumrind, D. (1971). Current patterns of parental authority. Developmental Psychology, 4(1), 1-103. http://dx.doi.org/10.1037/h0030372

Brannon, D., \& Dauksas, L. (2012). Increasing the expressive vocabulary of young children learning English as a second language through parent involvement. Procedia-Social and Behavioral Sciences, 69, 1324-1331. http://dx.doi.org/10.1016/j.sbspro.2012.12.069

Chen, H., \& Harris, P. (2009). Becoming school literate parents: An ESL perspective. Australian Journal of Language and Literacy, 32(2), 118-135.

Cojocariu, V. M., \& Mareş, G. (2014). A study on the primary school teachers' view upon the essential factors determining the (non) involvement of the family in the education of primary school students in Romania. Procedia-Social and Behavioral Sciences, 142, 653-659. http://dx.doi.org/10.1016/j.sbspro.2014.07.681

Dawson, C. (2002). How to choose your participants. Practical research methods, a user-friendly guide to mastering research. Wiltshire: Cromwell Press.

Desforges, C., \& Abouchaar, A. (2003). The impact of parental involvement, parental support and family education on pupil achievements and adjustment: A literature review. Research report No. 433. Department for Education and Skills, United Kingdom UK: Queen's Printer.

Gregory, E. (1998). Siblings as mediators of literacy in linguistic minority communities. Language and Education, 12(1), 33-54. http://dx.doi.org/10.1080/09500789808666738

Gregory, E. (2001). Sisters and brothers as language and literacy teachers: Synergy between siblings playing and working together. Journal of Early Childhood Literacy, 3, 301-322. http://dx.doi.org/10.1177/14687984010013004

Gubrium, J. F., \& Holstein, J. A. (2002). Handbook of interview research: Context and method. Thousand Oaks, CA: Sage Publications.

Guest, G., Namey, E. E., \& Mitchell, M. L. (2012). Collecting qualitative data: A field manual for applied 
research. Washington, DC: Sage Publications.

Hatch, J. A. (2002). Doing qualitative research in education settings. New York, NY: State University of New York Press.

He, T. H., Gou, W. J., \& Chang, S. M. (2015). Parental involvement and elementary school students' goals, maladaptive behaviors, and achievement in learning English as a foreign language. Learning and Individual Differences, 39, 205-210. http://dx.doi.org/10.1016/j.lindif.2015.03.011

Heigham, J., \& Croker, R. A. (Eds.). (2009). Qualitative research in applied linguistics: A practical introduction. London: Palgrave Macmillan.

Henderson, A. T., \& Mapp, K. L. (2002). A New Wave of Evidence: The Impact of School, Family, and Community Connections on Student Achievement. Annual Synthesis 2002. Austin, TX: National Center for Family and Community Connections with Schools.

Hernández, R., Fernández, C., \& Baptista, P. (2006). Metodología de la investigación. México: McGraw-Hill.

Hoover-Dempsey, K. V., Walker, J. M. T., Sandler, H. M., Whetsel, D., Green, C. L., Wilkins, A. S., \& Closson, K. (2005). Why do parents become involved? Research findings and implications. The Elementary School Journal, 106, 105-130. http://dx.doi.org/10.1086/499194

Hopkins, D. (2002). A Teacher's Guide to Classroom Research. Chapter 8. Philadelphia, PA: Open University Press, 102-128.

Jessel, J., Kenner, C., Gregory, E., Ruby, M., \& Arju, T. (2011). Different spaces: Learning and literacy with children and their grandparents in east London homes. Linguistics and Education, 22(1), 37-50. http://dx.doi.org/10.1016/j.linged.2010.11.008

Kim, H. Y. (2011). Parents' perceptions, decisions, \& influences: Korean immigrant parents look at language learning \& their children's identities. Multicultural Education, 18(2), 16-19.

Kukk, A., Rajalaane, R., Rei, M. L., \& Piht, S. (2015). Parents opinions on homework in the II stage of primary school (Estonian example). Procedia-Social and Behavioral Sciences, 171, 134-144. http://dx.doi.org/10.1016/j.sbspro.2015.01.099

Lee, J. S., \& Bowen, N. K. (2006). Parent involvement, cultural capital, and the achievement gap among elementary school children. American Educational Research Journal, 43(2), 193-218. http://dx.doi.org/10.3102/00028312043002193

MEN. (2016). Derechos Básicos de Aprendizaje Inglés 6 a 11. MEN.

Necşoi, D. V., Porumbu, D., \& Beldianu, I. F. (2013). The relationship between parental style and educational outcomes of children in primary school in Romania. Procedia-Social and Behavioral Sciences, 82, $203-208$. http://dx.doi.org/10.1016/j.sbspro.2013.06.246

Pavalache-Ilie, M., \& Țîrdia, F. A. (2014). Parental involvement and intrinsic motivation with primary school students. Procedia-Social and Behavioral $\quad$ Sciences, $607-612$. http://dx.doi.org/10.1016/j.sbspro.2015.03.113

Petchprasert, A. (2014). The influence of parents' backgrounds, beliefs about English learning, and a dialogic reading program on Thai kindergarteners' English lexical development. English Language Teaching, 7(3), 50-62. http://dx.doi.org/10.5539/elt.v7n3p50

Ringenberg, M., McElwee, E., \& Israel, K. (2009). Cultural capital theory and predicting parental involvement in Northwest Indiana schools. The South Shore Journal, 3, 86-124.

Senechal, M., LeFevre, J. A., Thomas, E. M., \& Daley, K. E. (1998). Differential effects of home literacy experiences on the development of oral and written language. Reading Research Quarterly, 33, 96-116. http://dx.doi.org/10.1598/RRQ.33.1.5

Volk, D., \& de Acosta, M. (2001). 'Many differing ladders, many ways to climb...': Literacy events in the bilingual classroom, homes, and community of three Puerto Rican kindergartners. Journal of Early Childhood Literacy, 1(2), 193-224. http://dx.doi.org/10.1177/14687984010012004

Walker, J. M., Hoover-Dempsey, K., Whetsel, D., \& Green, C. (2004). Parental involvement in homework. A review of current research and its implications for teachers, After School Program Staff, and Parent Leaders. Harvard: Harvard Family Research Projects.

Widding, G., \& Berge, B. (2014). Teachers' and parents' experiences of using parents as resources in Swedish 
primary education. Procedia - Social and Behavioral Sciences, 116, 1587-1593. http://dx.doi.org/10.1016/j.sbspro.2014.01.439

Xuesong, G. (2006). Strategies used by Chinese parents to Support English language learning voices of 'elite' university students. RELC Journal, 37(3), 285-298. http://dx.doi.org/10.1177/0033688206071302

\section{Copyrights}

Copyright for this article is retained by the author(s), with first publication rights granted to the journal.

This is an open-access article distributed under the terms and conditions of the Creative Commons Attribution license (http://creativecommons.org/licenses/by/4.0/). 